\title{
ELDERLY IMMIGRANTS' LABOR SUPPLY RESPONSE TO SUPPLEMENTAL SECURITY INCOME
}

\author{
Neeraj Kaushal* \\ CRR WP 2008-25 \\ Released: January 2009 \\ Draft Submitted: December 2008 \\ Center for Retirement Research at Boston College \\ Hovey House \\ 140 Commonwealth Avenue \\ Chestnut Hill, MA 02467 \\ Tel: 617-552-1762 Fax: 617-552-0191
}

* Neeraj Kaushal is an associate professor of social work at Columbia University and a faculty research fellow at the National Bureau of Economic Research. The research reported herein was pursuant to a Sandell grant from the U.S. Social Security Administration (SSA) funded as part of the Retirement Research Consortium (RRC). The findings and conclusions expressed are solely those of the author and do not represent the views of SSA, any agency of the Federal Government, the RRC, Columbia University or Boston College.

(C) 2009, by Neeraj Kaushal. All rights reserved. Short sections of text, not to exceed two paragraphs, may be quoted without explicit permission provided that full credit, including (C) notice, is given to the source. 


\title{
About the Center for Retirement Research
}

The Center for Retirement Research at Boston College, part of a consortium that includes parallel centers at the University of Michigan and the National Bureau of Economic Research, was established in 1998 through a grant from the Social Security

Administration. The Center's mission is to produce first-class research and forge a strong link between the academic community and decision makers in the public and private sectors around an issue of critical importance to the nation's future. To achieve this mission, the Center sponsors a wide variety of research projects, transmits new findings to a broad audience, trains new scholars, and broadens access to valuable data sources.

\author{
Center for Retirement Research at Boston College \\ Hovey House \\ 140 Commonwealth Avenue \\ Chestnut Hill, MA 02467 \\ phone: 617-552-1762 fax: 617-552-0191 \\ e-mail: crr@bc.edu \\ www.bc.edu/crr
}

\author{
Affiliated Institutions: \\ The Brookings Institution \\ Massachusetts Institute of Technology \\ Syracuse University \\ Urban Institute
}




\begin{abstract}
This paper examines the effect of changes in immigrant eligibility for Supplemental Security Income in 1996 on the employment and retirement behaviors of foreign-born elderly persons. I find that denial of SSI was associated with a 5 percentage point (15 percent) increase in the employment of non-citizen elderly men and a 5.6 percentage point (11 percent) decrease in their retirement rate. The estimated effects were higher for recent arrivals, a group most likely to be affected by the policy change. Further, while recent arrivals were more likely to increase part-time work, the earlier arrivals responded to the policy by increasing full-time employment. I find no consistent evidence that denial of SSI affected the employment of elderly immigrant women, but some evidence that it raised their retirement rate, specifically among those who immigrated in recent years.
\end{abstract}




\section{Introduction}

In recent years, labor force participation of the elderly in the US has undergone notable changes. The long-term trend in early retirement appears to have been reversed and employment among individuals aged 60 to 74 years has been rising steadily (Cahill et al., 2005; Gendell, 2001, 2006; Quinn, 1999). These trends are more pronounced among the foreign-born, who comprise 11 percent of the elderly population in the country (Borjas, 2007). This paper investigates whether these recent changes in immigrant labor force participation and retirement behaviors are associated with the Personal Responsibility and Work Opportunity Reconciliation Act (PRWORA) of 1996 that banned Supplemental Security Income (SSI) to a majority of elderly non-citizens. Partly as a result of this policy change, SSI receipt among non-citizens aged 60 to 74 declined from 13 percent in 1995 to four percent by $2006 .^{1}$

The stringent stipulations towards immigrant SSI eligibility were the result of a number of factors, foremost among them was the sharp increase in immigrants' dependence on SSI since the early 1980s. During 1982-1995, SSI receipt among immigrants increased six-fold from 128,000 to 785,000 cases (U.S. House Ways and Means Committee, 2004 Green Book). Immigrants, during this period, were more likely than the US born to receive SSI (Borjas and Hilton, 1996; Hu, 1998). Age at arrival in the US was found to be an important determinant of SSI dependence: immigrants entering the country at age 55 or less were less likely to receive SSI when they became eligible than those who arrived after they turned $55(\mathrm{Hu}, 1998)$. These factors led to concerns among policy experts and legislators that legal immigrants were bringing their parents to the US and after the mandatory waiting period of three years, putting them on SSI

\footnotetext{
${ }^{1}$ Author's estimates using the 1996 and 2007 March Current Population Surveys.
} 
(Haskins, 2007; Matloff, 1996). ${ }^{2}$ There was also a widespread suspicion that middlemen acting as translators were helping immigrants lie or pretend to have mental conditions so that they could receive SSI. In 1995, Congress appointed the General Accounting Office to conduct an inquiry into the existence of such fraudulent practices. ${ }^{3}$ A year later, in 1996, PRWORA denied SSI to all non-citizens except for those who had worked in the US for at least 40 'qualifying' quarters. ${ }^{4}$

How did denial of SSI affect retirement behavior and labor force participation of elderly immigrants? Denial of public support may have induced elderly immigrants to postpone retirement, and increase work effort since receipt of SSI for most immigrants is now contingent on their employment history in the US. The employment effect of this policy change will be more pronounced on elderly immigrants who have been in the US for less than 10 years because they will need additional work credits to become eligible for SSI or Social Security. Researchers have examined the effect of the 1996 PRWORA on most aspects of non-elderly immigrants' well-being but surprisingly there is little research on its effect on the elderly. ${ }^{5}$ Davies and Greenwood (2004) used Social Security Administration data from 1993-1999 to study the effect of welfare reform on elderly immigrants' SSI receipt. ${ }^{6}$ But there is no research on whether denial of SSI encouraged elderly immigrants to increase their employment and hours worked, and postpone retirement decisions. This research is important to get a full measure of the effect of PRWORA on immigrants, and to answer an important question confronting policy analysts:

\footnotetext{
${ }^{2}$ According to Matloff (1996), 45 percent of elderly immigrants in California received cash welfare in 1990.

${ }^{3}$ While GAO did not come up with the exact level of fraudulent SSI applications by non-English speaking immigrants, it cited cases of fraud in California and Washington (see GAO, 1995).

${ }^{4}$ If a working immigrant received food stamps or cash welfare during a quarter, that quarter is considered 'unqualifing'. Non-citizen permanent residents who arrived in the country after August 22, 1996 are eligible for SSI if they are refugees or asylees or have been in active duty Armed forces (see Parrott et al., 1999, for details on immigrant provisions in PRWORA).

${ }^{5}$ Note that the non-immigrant provisions in the 1996 Act only targeted non-elderly adults and their children.

${ }^{6}$ For research on the effects of PRWORA on immigrant use of means-tested programs see: Borjas (2001), Fix and Passel (1999, 2002), Haider et al. (2004), Kaushal (2005), Kaestner and Kaushal (2007), Loftstorm and Bean (2002), Van Hook and Bean (1999), Van Hook (2003).
} 
whether public and private policies and programs for the elderly create barriers to work and whether these barriers should be eliminated by restructuring these programs, given the challenges posed by the growing size of the elderly population in the US. While researchers have studied the effect of Social Security on the labor supply of elderly persons, there is not much work on the impact of the SSI program on labor supply, in particular the employment and retirement decisions of the foreign-born who have been a major beneficiary of the program.

\section{Trends in Immigrant Receipt of SSI}

Figure 1 presents the trends in SSI receipt among non-citizens aged 65 or older, disabled/ blind non-citizens and all non-citizens (the elderly and disabled/blinds combined) during 19822006, based on the Social Security Administration data. The period prior to 1996 is marked by a steady increase in SSI receipt for the two groups of non-citizens. This increase is reflective of both the large volume of immigrant inflows in the past two decades and their composition. For instance, recent inflows of immigrants are more likely than natives to be high-school dropouts (Census Bureau, 1995, 2004), and thus more likely to become dependent on means-tested programs. As expected, PRWORA reversed the upward trend in immigrant dependence on SSI. During 1995-1997, the number of elderly non-citizens on SSI declined sharply by $20 \%$ or 92,020 cases. In 1998, Congress restored eligibility to immigrants who were receiving SSI in August 1996, when PRWORA was enacted.

During 1998-2006, SSI receipt among elderly non-citizens registered a slow but steady decline of approximately 3000 cases a year. SSI receipt among blind/disabled non-citizens fell slightly during 1995-1997, and followed by a modest increase. In 1982, as many as 71 percent 
of the non-citizens receiving SSI were elderly. By 2006, their proportion had declined to 50 percent.

Traditionally, immigrant dependence on SSI has been higher than those of natives, as shown by Figure 2 based on data drawn from the March Current Population Survey for elderly persons aged 60 to $74 .^{7}$ During 1993-1995, the earliest period for which data on nativity in the Current Population Survey are available, nine percent of the elderly foreign-born population (aged 60 to 74) received SSI; the corresponding proportion was two percent for native-born elderly persons. $\mathrm{Hu}$ (1998) postulates three hypotheses explaining the gap in SSI receipt between elderly immigrants and natives: (i) elderly immigrants may be attracted to the US by its SSI scheme, which is more generous than the pension schemes in most countries of immigrant origin, (ii) since recently arrived elderly immigrants do not have sufficiently long earnings history in the US to be able to collect Social Security benefits, they are more likely than natives to have low incomes and thus be eligible for SSI, and (iii) selective emigration of more successful immigrants may result in a larger proportion of elderly immigrants being poorer, and thus in need of state support. Empirical evidence to support selective emigration of more successful immigrants (the last of the three hypotheses), however, is lacking. Indeed, most prior research advocates the reverse phenomenon, i.e. selective emigration of less successful immigrants (Borjas 1985, 1987; Duleep and Dowhan 2002; Hu 2000).

The first two hypotheses indicate that elderly immigrants' duration of stay in the US is a factor in determining their dependence on SSI, those with a shorter duration of stay are more likely to receive SSI than those with longer durations. Data in Figure 2 support this assertion: during 1993-1995, 17 percent of elderly (aged 60-74) foreign-born persons who had lived in the

\footnotetext{
${ }^{7}$ Note that the decline in non-citizens' receipt of SSI appears to be greater in Figure 2 than in Figure 1. One explanation for the difference is that Figure 2 pertains to individuals aged 60 to 74, whereas Figure 1 includes all non-citizens aged 65 or above.
} 
US for 10 years or less received SSI. The corresponding figure was seven percent in the case of elderly foreign-born persons who have been in the US for more than 10 years.

The 1996 PRWORA that changed the rules of immigrant eligibility for SSI weakened the premises for these first two hypotheses. Partly as a result, post-1996 immigrant dependence on SSI has declined steadily such that in 2006 only three percent of the elderly foreign-born persons aged 60-74 received any SSI. Receipt of SSI among US born elderly persons, on the other hand, remained mostly unchanged as did the policy concerning their SSI eligibility.

The 1996 welfare reform law has made the rules for immigrant qualification for SSI somewhat similar to the rules for receiving Social Security in the sense that immigrant eligibility for both programs now requires a ten-year work history in the US. Thus elderly immigrants, who migrated less than 10 years ago, are ineligible for both SSI and Social Security. These changing eligibility rules underlie the post-1996 trends in SSI receipt among recent and older (by duration of stay in the US) immigrants; the declining trend in SSI receipt is more pronounced among the recently arrived (in the US for 10 or fewer years) foreign-born elderly persons than among the earlier arrivals, thus eliminating the 10 percentage points (during 1993-1995) gap in the two groups' dependence on SSI by 2005-2006.

\section{Methodology}

The objective of this paper is to examine if denial of SSI encouraged elderly foreign-born persons to increase their labor market participation and postpone their retirement decisions. The hypothesis underlying the empirical analysis is straight forward: the 1996 welfare law restricted SSI eligibility of most non-citizens conditional on their having worked 40 'qualifying' quarters in the US. This may have induced elderly immigrants to continue to work beyond the 
conventional retirement age. Since elderly immigrants who have been in the US for more than 10 years are more likely to have the required employment history in the US to either receive SSI or SS, the employment effect of change in policy would be greater on recent arrivals (in the US for $\leq 10$ years). I begin the analysis with the following model applied over a sample of individuals aged 60 to 74 years using the Current Population Survey Outgoing Rotation Group data:

$$
\begin{aligned}
& E_{i j t}=\beta_{j}+\beta_{j t}+\beta_{j m t}+\beta_{t}+\beta_{c}+\lambda\left(\text { Policy }_{t} * I_{m}\right)+\lambda_{1} I_{m}+X_{i j t} \Gamma+u_{i j t} \\
& i=1, \ldots, N \text { (persons) } \\
& \mathrm{m}=\text { foreign - born } \\
& j=1, \ldots, 51 \text { (states) } \\
& t=\text { year of survey }
\end{aligned}
$$

In Equation (1) $E_{i j t}$ is a labor market outcome (whether currently employed, hours worked per week including zeros, whether currently retired, whether works part-time or full-time) of individual $\mathrm{i}$ living in state $\mathrm{j}$ in year $\mathrm{t}$, and is a function of Policy $_{t}$ - an indicator for whether the observation is taken from the post-1996 period; $I_{m}$ is an indicator for whether the elderly person is foreign-born; $X_{i j t}$, a vector of demographic variables namely age (a dummy variable for each year of age), marital status, education (a dummy variable for each of the following categories of educational attainment: less than high-school, high-school, some college, and BA or higher degree), citizenship status; and number of years lived in the US and state $\left(\beta_{j}\right)$, country of birth $\left(\beta_{c}\right)$ and year $\left(\beta_{t}\right)$ fixed effects and state-specific linear trends which are allowed to differ for immigrants and natives $\left(\beta_{j t} ; \beta_{j m t}\right)$. To allow for differences in employment and retirement behavior by gender, all analysis is done separately for men and women. 
The coefficient $\lambda$ provides the difference in the labor market outcome (e.g. whether currently employed, whether currently retired) between immigrants and natives in the pre- versus post-1996 period, after adjusting for demographic variables and state-specific linear trends. Although not shown in equation (1), unless statistical tests permit otherwise, regressions also allow the effect of all observed factors to be different for immigrants and natives. If time varying factors correlated with the policy change affected the labor market outcomes of immigrants and natives in the same manner, $\lambda$ would provide the estimated effect of denial of SSI on elderly immigrants. I also repeated regressions with controls for monthly state unemployment rate. The results were unaffected by the inclusion of this control. ${ }^{8}$

An equation similar to (1) can be used to examine the effect of SSI ineligibility on recent and older (in terms of period of stay in the US) immigrants:

$$
\begin{aligned}
E_{i j t}= & \hat{\beta}_{j}+\hat{\beta}_{t}+\beta_{c}+\beta_{j t}+\beta_{j m t}+\hat{\lambda}_{N}\left(\text { Policy }_{t} * \operatorname{Im}_{n}\right)+\hat{\lambda}_{o}\left(\text { Policy }_{t} * \operatorname{Im}_{o}\right) \\
& +\hat{\lambda}_{1} \operatorname{Im}_{n}+\hat{\lambda}_{2} \operatorname{Im}_{o}+X_{i j t} \hat{\Gamma}+\hat{u}_{i j t}
\end{aligned}
$$

Equation (2) has two more variables in addition to those in equation (1): $\operatorname{Im}_{n}$ is equal to 1 if the immigrant has been in the US for 10 or fewer years, otherwise 0 , and $\operatorname{Im}_{0}$ is equal to 1 if the immigrant is in the US for more than 10 years, otherwise 0 . US-born elderly persons are the category of comparison. Symbol ${ }^{\wedge}$ is used to distinguish parameters from equation (1). Since immigrants who have been in the US for less than 10 years will not have the required employment credits to be eligible for either SSI or Social Security, the estimated value of $\hat{\lambda}_{N}$ should be greater than the estimated value of $\hat{\lambda}_{o}$. If not, that would suggest that the estimation

\footnotetext{
${ }^{8}$ Since state unemployment rate is somewhat endogenous to labor market outcomes of elderly immigrants, I have elected not to include this control in the results presented in the paper.
} 
strategy outlined in equations (1) and (2) provided biased estimates of the effect of SSI restrictions on employment and retirement behaviors of elderly foreign-born persons.

The estimated effects of SSI restrictions on elderly immigrants using equations (1) and (2) are based on the assumption that time-varying factors correlated with policy affected immigrants and natives in the same manner, after adjusting for state level linear trends that are allowed to differ for immigrants and natives. Ideally, the assumption should be tested on a population identical to elderly immigrants, but unaffected by the changes in immigrant SSI eligibility. Post-1996, only two groups of non-citizens remain eligible for SSI: immigrants who were on SSI when the law was passed and those who had worked in the US for 40 quarters during which they did not receive either food stamps or cash welfare. Most datasets do not provide information that can enable us to identify these immigrants. ${ }^{9}$ I test the above assumption on immigrants aged 45-54, who are similar to elderly immigrants in terms their place of birth but unlikely to be affected by the SSI provisions in the 1996 law (at least in the short term) since they are ineligible for SSI till they turn 65. Thus if the estimated value of $\lambda$ in analysis with samples restricted to non-elderly adults (aged 45-54) is close to zero that would provide some evidence that the research strategy adopted in equation (1) is valid. I select this age group since PRWORA also denied cash welfare to immigrant families who entered the country after 1996. Denial of cash welfare to immigrants under PRWORA affected relatively younger low-educated single mothers e.g. those aged 18-44, who entered the country after 1996. In response to the policy change, these younger foreign-born single mothers may have increased their employment effort, thus it would be inappropriate to use the younger group for comparison purposes.

\footnotetext{
${ }^{9}$ Using the 1996 panel of the Survey of Income and Program Participation, I examined the trend in employment of elderly immigrants (aged 55-74) who were on SSI in 1996. This group had close to zero employment rate through out the four-year period of the 1996 SIPP.
} 
Elderly immigrants may also change their employment and retirement behaviors in response to the other provision of PRWORA (other than SSI restrictions e.g. restrictions on cash welfare and food stamp) that affected transfer of resources to other family members. Thus the comparison group approach applied here is important. If the estimated effect of policy on immigrants aged 45 to 54 is statistically significant that would imply that the methodology outlined above is not able to effectively purge the effect of other time-varying effects, e.g. the indirect effect of the other provisions of PRWORA on elderly immigrants' employment and retirement behaviors.

Another source of potential bias in estimates of $\hat{\lambda}_{o}$ and $\hat{\lambda}_{N}$ using equation (2) may arise if elderly immigrants who migrated in recent years chose to postpone retirement for a longer period than did immigrants who arrived in earlier years. This difference could be due to changes in immigrant composition caused by the policy (e.g. the policy discouraging inflows of immigrants who are likely to depend on state programs). If so, equation (2) will estimate the direct effect of policy on immigrant employment and retirement behavior as well as its indirect impact via changes in immigration patterns i.e. by increasing inflows of elderly or near elderly persons with higher employment rates. To examine whether recent immigrants were in general more likely to work, irrespective of their immediate vulnerability to changes in eligibility for SSI, I estimate equation (2) on a sample of non-elderly adults (aged 45-54 years). Since in the short run, this group is less likely to be affected by the policy change than elderly immigrants, the estimated values of $\hat{\lambda}_{o}$ and $\hat{\lambda}_{N}$ for this group should be modest and statistically not different from zero. If, for non-elderly adults, the estimated value of $\hat{\lambda}_{N}$ is greater than that of $\hat{\lambda}_{o}$, that would be an indication that recent immigrants are in general, irrespective of their age, more 
likely to work and that the estimates based on equation (2) are biased. Finally, I estimate equations (1) and (2) by restricting the immigrant samples to those who were in the country when PRWORA was passed. Coefficients from this analysis will not have confounding effects on account of recent immigration trends.

\section{Data}

The primary analysis in this study is based on the Current Population Survey monthly outgoing rotation group files (CPS-ORG) for January 1994 to December 2005. From 1994 onwards, CPS has started providing information on a respondent's country of birth, citizenship status and years lived in the US, information essential to conduct this analysis. The other unique advantage of the CPS is its large size, which is crucial given my interest in a narrowly defined population of foreign-born elderly persons.

The CPS is rich in demographic information of respondents, such as their age, gender, marital status, race, education, and state of residence, in addition to data on whether retired, current employment status, hours worked per week and, for those working, whether it's full-time or part-time work. This information is used to create key control variables and the outcomes of interest. Further, monthly state unemployment rate from the Bureau of Labor Statistics is matched with the micro-level data by month, state and year and used as a control in some regressions.

From 1994 onwards, the CPS has also started providing data on whether the respondent has a disability, which are used to exclude disabled elderly persons from the analysis. The 1997 Balanced Budget Act sanctioned SSI provisions for immigrants lawfully residing in the US on 
August 22, 1996 if they become disabled in the future. ${ }^{10}$ This may have increased the attractiveness of the Disability Insurance (DI) to immigrants, and consequently increased the number of immigrants applying for DI. I checked for this possibility in the CPS sample. During 1994-1996, six percent of the foreign-born respondents aged 60 to 74 mentioned that they had a disability. The proportion remained the same during 1997-2005, the post PRWORA period covered by this study. Further, I also did the analysis on a combined sample of able-bodied and disabled persons. The results were similar to those obtained from samples that excluded disabled persons.

The target of SSI provisions in PRWORA is non-citizens. Foreign-born citizens are not treated differently from the US-born. Ideally, foreign-born citizens should be excluded from the analysis as they are unaffected by the policy change. However, if PRWORA induced immigrants to become citizens so that they could continue to have access to means-tested programs, exclusion of citizens would result in a selectivity bias. There is evidence of increased naturalization throughout the 1990s. According to Fix and Haskins (2002), the increase in naturalizations during this period was mainly the result of increased immigration in the early 1990s and the 1986 Immigration Reform and Control Act that granted permanent legal status to approximately 2.7 million immigrants. However, it is not possible to rule out that some immigrants naturalized in response to welfare reform and its discriminatory treatment of noncitizens (Van Hook, 2003). Therefore, I begin the analysis by combining the samples of foreignborn citizens and non-citizens. This approach eliminates the selection bias relating to naturalization. I also do the analysis for a more precisely defined target group of non-citizens.

The CPS does not provide data on the legal status of non-citizens. Changes in immigrant composition on account of increased inflows of undocumented immigrants in the post-PRWORA

\footnotetext{
${ }^{10}$ The 1996 law eliminated alcoholism and drug addiction as a basis for the finding of a disability.
} 
period may bias the outcome of any pre- to post-PRWORA analysis on account of changes in sample composition in the post-PRWORA period. Passel (2005) who has done detailed analysis on the characteristics of undocumented immigrants shows that there are virtually no undocumented immigrants above the age of 65 , and only 1.1 million ages 40 or over. Thus, increased inflows of undocumented immigrants in recent years are not likely to affect the results of this analysis as it is focused on near elderly or elderly immigrants who have a low probability to be undocumented (Passel 2005).

\section{Results}

Descriptive analysis

Table 1 presents descriptive data on the samples of foreign-born and US born elderly men and women aged 60 to 74 . There are several points to note about these groups. The average educational attainment of foreign-born elderly men (women) is lower than the average educational attainment of US-born elderly men (women), but there is also greater variance in the educational attainment of the foreign-born. A third of foreign-born elderly men and 38 percent of foreign-born elderly women did not have a high-school degree. The corresponding figures for the US born were 21 percent high-school dropouts among men and 20 percent among women. Foreign-born elderly men (women) were less likely to have a high-school degree or some college education than the US born elderly men (women). At the same time, the foreign-born were slightly more likely than natives to have at least a BA degree.

Data on labor market outcomes show that in the pre-PRWORA period, foreign-born elderly men were somewhat more likely to work and less likely to have taken retirement than similar native men; foreign-born elderly women were slightly less likely to work than US born 
elderly women, but the latter also had a slightly higher retirement rate. ${ }^{11}$ Overall, during $1994-$ 1996, 37 percent of foreign-born elderly men and 21 percent of foreign-born elderly women were employed. The corresponding numbers were 34 percent for native men and 22 percent for native women. In the post-1996 period, the average employment of all four groups increased and in percentage point terms, the increase was somewhat higher for the foreign-born among elderly men and the US-born among elderly women. As a result, in the post-reform period the gap in labor market participation of foreign- versus US born men (and women) widened.

\section{Multivariate Analysis}

Table 2 provides estimated effects of SSI ineligibility under the 1996 law on employment, hours worked and retirement behaviors of elderly foreign-born men aged 60 to 74 . The top panel presents results for all foreign-born men and the bottom panel restricts the sample of foreign-born men to non-citizens. Each figure in the top row of both panels is from a separate regression based on equation (1). Figures in the bottom two rows of both panels are based on equation (2) that allows the effect of policy to differ by the elderly immigrant's length of stay in the US. The US born elderly men are the category of comparison. For each outcome, estimates are computed using two models. The first model includes controls for age, race, education, marital status, whether the respondent is foreign-born, citizenship status and years of stay in the US for the foreign-born, month of the year, year, state and country fixed effects. Additional controls for state-specific linear trends are included in the second model and these trends are allowed to differ for immigrants and natives. The second model also allows state fixed effects to differ for foreign-born and US-born men. The effects of all other variables are restricted to be the

\footnotetext{
${ }^{11}$ According to the CPS data for 1994-2005, 10 percent of the foreign-born sample (aged 60 to 74) of women reported not being in the labor force for reasons other than retirement or disability; the corresponding number was five percent for US born elderly women.
} 
same for the two groups since statistical tests failed to reject the restriction. Heteroskedasticity adjusted standard errors clustered on states are in parentheses.

These results suggest that denial of SSI is associated with a 2.7 percentage point increase in the employment of foreign-born elderly men (or a 7.1 percent increase over the mean employment rate of $37 \%$ during 1994-96). The estimated effect is a statistically significant 7.1 percentage point increase for elderly foreign-born men who have been in the US for 10 or fewer years; and a significant 1.9 percentage point increase for foreign-born men who have lived here for more than 10 years. Statistical tests reject the hypothesis that the increase in employment is the same for the two groups of foreign-born men. Estimated effects remain roughly the same when models include state-specific linear trends that are allowed to be different for the foreignborn and natives.

PRWORA did not change the SSI eligibility for foreign-born citizens. The estimated effect of the policy should therefore be higher when the foreign-born sample is restricted to noncitizens. Point estimates in panel 2 suggest this to be the case: denial of SSI is found to be associated with a 4.6 to five percentage point increase in the employment of non-citizen elderly men (or a 14 to 15 percent increase over the mean employment rate of $33 \%$ for non-citizens during 1994-1996). Again, the estimated effect is higher on recent arrivals, and inclusion of state-specific linear trends does not alter the basic results.

Columns 3-4 present the estimated effect of policy on average weekly hours worked (including zeros for non-workers), and suggest that elderly foreign-born men increased their weekly working hours by 50 minutes in response to the policy that denied them eligibility for SSI. The increase is estimated to be a statistically significant one hour and 43 minutes for 
recently arrived foreign-born men and a statistically insignificant 25 minutes for earlier arrivals. The coefficients turn statistically insignificant when models include state-specific linear trends.

The policy is estimated to be associated with a 91 minutes increase in weekly working hours of non-citizen elderly men; an over two hours increase for non-citizens, in the US for 10 or fewer years, and a statistically insignificant 48 minutes rise for non-citizen men, who have been in the country for more than 10 years. Point estimates become somewhat higher with models that include state-specific linear trends.

For elderly men, employment is generally the converse of retirement, and results in columns 5-6 confirm this fact. Denial of SSI is found to be associated with a 2.2 to 2.5 percentage point (3.9 to 4.4 percent over the mean pre-policy retirement rate of 57 percent) decline in the probability of foreign-born elderly men retiring, and the decline is greater for the recent arrivals who are unlikely to have the work history to be eligible for either social security or SSI. The estimated coefficient is a statistically significant minus 4.4 to 4.9 percentage point for foreign-born persons who have been in the country for 10 or fewer years, and a statistically significant minus 1.7 to 2.1 percentage point for foreign-born men who have been in the US for more than 10 years. Further, statistical tests fail to reject the hypothesis that the estimated coefficients are the same for the two groups.

Ineligibility to receive SSI lowered the probability of retirement among non-citizen elderly men by 4.3 to 5.6 percentage points ( 8.6 to 11.2 percent over the mean retirement rate of 50 percent for non-citizens during 1994-1996). The estimated effect is a 6 to 6.9 percentage point decline in retirement for recent arrivals and a 3.5 to 4.8 percentage point decline for earlier arrivals, and a statistical test fails to reject the hypothesis that the two groups are similarly 
affected by the policy change. As in the analysis on employment, inclusion of state-specific linear trends does not alter the result.

One potential problem in the results presented in Table 2 is that some of the recent immigrants (in the US $<10$ years) are likely to have arrived in the US after 1996. These immigrants may have higher employment rates and lower retirement rates than elderly or near elderly immigrants who were in the country when the law was passed and who were arguably the primary target of the SSI provisions in PRWORA. To address this issue, I first did the analysis by restricting the immigrant population to those who were in the country the law was passed. The results were similar to those in Table $2 .{ }^{12}$ I also did the analysis by restricting the sample in the post-PRWORA period to fewer years. Specifically, I repeated the analysis in Table 2 on the CPS sample for 1994-2002, thus indirectly restricting the number of post-PRWORA immigrants in the sample of recent immigrants. The estimated results were similar to those presented in Table $2 .^{13}$

Next, I examine the effect of SSI on the employment, hours worked and retirement behavior of elderly foreign-born women. The results are presented in Table 3, which has the same layout as Table 2. These results suggest that the immigrant provision under the 1996 law was associated with a statistically significant 1.1 percentage point decline in the employment of foreign-born women. Estimated effects turn insignificant in models that include state-specific linear trends and in models that stratify the effect by foreign-born persons' duration of stay in the US. The effect of SSI eligibility on weekly working hours of foreign-born women is also found to be modest and statistically insignificant using various models, confirming the findings in column 2 (panel 1) that changes in eligibility for SSI did not have any effect on the employment

\footnotetext{
${ }^{12}$ There were only 599 men in the immigrant sample for 1994-2006 who arrived in the country after 1996.

${ }^{13}$ For space consideration, these results are not presented, but can be obtained from the author upon request.
} 
of foreign-born elderly women. Results in Panel 2 show that the policy change lowered the employment and hours worked of non-citizen elderly women (the coefficients are weakly significant), but the estimates turn statistically insignificant in models that allow the policy effect to be different for recent and older (by period of residence in US) elderly immigrants.

In regressions with whether currently retired as dependent variable, the coefficient of interaction between foreign-born and policy is found to be small and statistically insignificant. Models that stratify foreign-born elderly women by their duration of stay in the US, however, suggest that SSI ineligibility was associated with recent cohorts of elderly women increasing their retirement rate by a statistically significant 3.7 percentage point, while the retirement effect on the earlier cohorts of elderly women is modest and statistically insignificant. Point estimates show that the policy change had a somewhat larger effect on the retirement behavior of elderly non-citizen women (panel 2), in particular on those who have been in the country for 10 or fewer years.

To sum up, the above analysis suggests that denial of SSI was associated with an increase in the employment and average weekly working hours of foreign-born men, and a reduction in their retirement rate. The increase in employment and hours worked was greater among recent immigrants, who were most likely to be affected by the SSI provisions for immigrants, than among immigrants who arrived earlier. On the other hand, this analysis fails to provide any consistent evidence that denial of SSI to immigrants affected the employment and weekly hours worked of foreign-born women. It is likely that elderly immigrant women need a greater incentive to increase employment because of their traditional role and contribution in family work, e.g. taking care of grandchildren. This finding resonates with some previous research that shows that elderly women value retirement more than elderly men and that they are more willing 
to give up incomes in favor of retirement than similarly placed men (Danø, Ejrnæs, \& Husted, 2004). There is some evidence, however, that the change in policy was associated with recently arrived foreign-born elderly women choosing to retire in larger numbers after 1996.

Theoretically, it seems difficult to explain why denial of SSI would encourage retirement among recently arrived elderly foreign-born women. It is possible that some immigrant women may be responding to possible increases in family earnings due to increased employment of immigrant men. Unfortunately, CPS-ORG does not provide details on family income, therefore, it is not possible to control for the income of other family members in these regressions. There is also a possibility that some elderly immigrant women may be retiring in response to higher demand for childcare for their grandchildren due to increases in employment of younger women family members caused by PRWORA that denied or restricted cash welfare to immigrants.

Next, I examine whether denial of SSI encouraged elderly immigrant men to increase full-time or part-time work. The dependent variable in this analysis has three values: worked full-time last week, worked part-time last week, and did not work (the category of comparison). Models similar to equations (1) and (2) are estimated using multinomial logit models. Table 4 presents the estimated coefficients and marginal effects. Heteroskedasticity adjusted standard errors clustered on states are presented in parentheses.

Figures in rows 1, 4, 7 and 10 are from separate regressions; and figures in rows 2-3, 5-6, 8-9 and 11-12 are from separate regressions in which the sample of foreign-born persons is stratified by the length of their stay in the US. Each regression includes controls for age, race, education, marital status, whether the respondent is foreign-born, years lived in the US and citizenship status, month of the year, year and state fixed effects. These regressions show that denial of SSI increases foreign-born men's probability of working part-time by 1.5 percentage 
points and full-time by 2.1 percentage points. In models that stratify the foreign-born sample by length of US residency, denial of SSI is estimated to increase part-time employment of recent cohorts of foreign-born elderly men by a statistically significant 6.2 percentage point and their full-time employment by a statistically insignificant 2.6 percentage point. Foreign-born elderly men who have been in the US for more than 10 years, on the other hand, did not increase their part-time employment, but increased their full-time effort by a statistically significant two percentage point.

As in the analysis on employment and weekly hours worked, point estimates become larger when the sample of foreign-born elderly men is restricted to non-citizens. These estimates suggest that denial of SSI increased the part-time employment of non-citizens by a statistically significant 3.3 percentage point and their full-time employment by a significant 2.9 percentage points. Recently arrived elderly immigrant men increased their part-time employment by a statistically significant 8.2 percentage point and their full-time employment by 3.6 percentage points. Elderly men who arrived earlier ( $>10$ years ago), on the other hand, did not experience any increase in part-time employment, but a statistically significant 2.5 percentage point increase in full-time employment. The estimated effects of policy on the part-time and full-time employment of elderly immigrant women were modest and statistically insignificant, as expected given the findings in Table 3 .

To sum up, the analysis so far suggests that denial of SSI was associated with an increase in the employment and average weekly working hours of foreign-born men, and a reduction in their retirement. The increase in employment and hours worked was greater among recent arrivals. The analysis also suggests that the policy was associated with an increase in part-time as well as full-time employment of elderly men. However, recently arrived elderly men, who 
were more likely to be affected by the policy, were more likely to respond by increasing parttime work effort, while the earlier arrivals responded by increasing full-time work effort. Finally, there is no consistent evidence that denial of SSI affected the employment of foreignborn elderly women, but some evidence that it raised the retirement rate of recently immigrated elderly women.

It is likely that the estimated effect of the policy on elderly immigrant men was on account of factors correlated with the policy that affected the employment and retirement behaviors of immigrant men, and but not of US born men. One way to examine this possibility is by studying the effect of the 1996 policy on the employment, hours worked and retirement behavior of foreign-born non-elderly adults aged 45 to 54 , who were less likely to be affected by the policy change. Able-bodied immigrants can apply for SSI only after they turn 65 . Therefore, the 1996 law could not have had any immediate effect on the SSI receipt of non-elderly ablebodied immigrants, and a much modest effect on their employment and retirement (as compared to the policy's effect on elderly immigrants). However, it is not possible to entirely rule out employment effect on non-elderly adults, especially on those who have been in the US for less than 10 years and need to accumulate work credit to ensure future SSI eligibility.

Table 5 presents the results of this analysis. The policy change is associated with a statistically significant 1.2 percentage point increase in the employment of foreign-born men. The estimated effect is a statistically significant 4.3 percentage point increase for men who have been in the US for 10 or fewer years and an insignificant 0.3 percentage point increase for men who have been here for more than 10 years. The policy change was associated with a statistically significant 36 minutes increase in weekly working hours of all foreign-born men; a significant 102 minutes increase for recent immigrants and an insignificant 18 minutes increase 
for earlier arrivals. Estimated effects, however, become smaller and statistically insignificant in regressions that include state-specific linear trends. In addition, denial of SSI did not affect the retirement rate of non-elderly foreign-born men. This provides some evidence that the changes in employment and retirement behaviors observed in Table 2 were not on account for secular changes in factors that influenced all foreign-born men, elderly as well as non-elderly.

The bottom panel in Table 5 presents the estimated coefficients of the effect of change in SSI eligibility rules on the employment and retirement behaviors of non-elderly adult women. Estimates in this panel are modest and mostly statistically insignificant, in particular for models that include state-specific linear trends.

\section{Conclusions}

This paper examined how the 1996 Personal Responsibility and Work Opportunity Reconciliation Act that denied non-citizens access to SSI unless they had worked in the US for at least 40 quarters affected the employment and retirement behaviors of foreign-born elderly men and women. The analysis suggests that the policy was associated with a five percentage point (15 percent) increase in the employment of non-citizen elderly men and an increase of two hours in their weekly work effort. The policy was also associated with a 5.6 percentage point (11 percent) decrease in their retirement rate. The estimated effect of change in employment and weekly hours worked was found to be statistically greater for recent arrivals (in the US for 10 or fewer years) than for those who have been in the country for more than 10 years. Further, the analysis indicates that while recently arrived elderly men, who were more likely to be affected by the policy, were more likely to respond to the policy change by increasing their part-time work effort, the earlier arrivals mostly responded by increasing full-time employment. The results 
remain robust when the analysis is restricted to pre-PRWORA arrivals or when the sample is restricted to $1994-2002$.

The regression analysis does not provide any consistent evidence that foreign-born elderly women changed their employment and weekly working hours in response to the policy that denied them access to SSI. There is some evidence, however, suggesting that the policy was associated with recently arrived foreign-born elderly women choosing to retire in larger numbers after 1996. It may be that elderly immigrant women's labor supply is affected by increased family income on account of increased work effort by elderly immigrant men. At the same time, some elderly immigrant women may be retiring in response to higher demand for childcare for their grandchildren due to increases in employment of younger women in the family associated with PRWORA that denied or restricted cash welfare to immigrants (Kaestner and Kaushal 2007). It is also likely that elderly immigrant women need a greater incentive to increase employment because of their traditional role and contribution to family work, e.g. taking care of grandchildren. This finding resonates with some previous research that shows that elderly women value retirement more than elderly men and that they are more willing to give up incomes in favor of retirement than similarly placed men (Danø, Ejrnæs, \& Husted, 2004).

To test whether the estimated effect of policy on elderly immigrant men was on account of factors correlated with the policy that affected the employment and retirement behaviors of all immigrant men, but not of US born persons, I examined the effect of the 1996 policy on the employment, hours worked and retirement behavior of foreign-born non-elderly adults aged 45 to 54, who were less likely to be affected by the policy change. The estimated effects in this analysis were found to be modest and statistically insignificant, suggesting that the change in 
employment and retirement behavior observed for elderly foreign-born men were not on account of some secular changes that affected all immigrants, elderly as well as non-elderly.

The findings from this analysis thus show that the 1996 PRWORA affected the employment and retirement behavior of elderly foreign-born men, a demographic group to which researchers have paid little attention, even though there was tremendous concern among policy makers regarding the growing dependence of this group on SSI prior to PRWORA enactment (Haskins, 2007; Matloff, 1996; GAO 1995). This study shows that at least part of the relative increase in employment among immigrant elderly men (as compared to elderly native men) in recent years was on account of the changes in immigrants' SSI eligibility, which dried up a potential source of income for this group. 
References

Borjas, G. J. 1985. "Assimilation, Changes in Cohort Quality, and the Earnings of Immigrants." Journal of Labor Economics 3(4):463-89.

Borjas, G. J. 1987. "Self-selection and the Earnings of Immigrants", American Economic Review, 77.

Borjas G. J. 2001. Welfare Reform and Immigration. In Blank, Rebecca M., and Ron Haskins, eds., The New World of Welfare. Washington, DC: Brookings Institution.

Borjas G. J. 2007. "Social Security Eligibility and the Labor Supply of Elderly Immigrants", Paper presented at the $9^{\text {th }}$ Annual Joint Conference of the Retirement Research Consortium Challenges and Solutions for Retirement Security.

Borjas, George and Lynette Hilton. December 1995. "Immigration and the Welfare State: Immigrant Participation in Means-Tested Entitlement Programs." The Quarterly Journal of Economics, Vol. 111, No. 2. (May, 1996), pp. 575-604.

Cahill, Kevin E., Michael D. Giandrea and Joseph F. Quinn. 2005. "Are Traditional Retirements a Thing of the Past? New Evidence on Retirement Patterns and Bridge Jobs", Boston College Working paper 626.

Census Bureau. 2004. "The Foreign-Born Population of the United States: 2003." U.S. Department of Commerce, Economics and Statistics Administration, U.S. Census Bureau.

Census Bureau. 1995. "Foreign-Born Population of the United States Current Population Survey - March 1995: Detailed Tables.” U.S. Department of Commerce, Economics and Statistics Administration, U.S. Census Bureau. http://www.census.gov/population/www/socdemo/foreign/for95dtabs.html

Dano, A. M., \& M. Ejrnæs, \& L. Husted, 2004. "Do Single Women Value Early Retirement more than Single Men?," CAM Working Papers 2004-06, University of Copenhagen. Department of Economics. Centre for Applied Microeconometrics.

Davies, P. and M. J. Greenwood. 2004. "Welfare reform and Immigrant Participation in the Supplemental Security Income Program.” Working Paper \#2004-087, Michigan Retirement Research Center.

Duleep, H. O. and D. J. Dowhan. 2002. "Insights From Longitudinal Data on the Earnings Growth of US Foreign-Born Men." Demography 39(3):485-506.

Fix, Michael and Jeffrey Passel. 1999. “Trends in Noncitizens' and Citizens' Use of Public Benefits Following Welfare Reform: 1994-97.” Urban Institute, Washington, DC.

Fix, Michael and Jeffrey Passel. 2002. “The Scope and Effect of Welfare Reform's Immigrant 
Provisions." Assessing the New Federalism: Discussion papers, Urban Institute, Washington DC.

GAO. 1995. "Disability Program Vulnerable to Applicant Fraud When Middlemen Are Used" General Accounting Office Report to the Chairman, Special Committee on Aging, U.S. Senate, US General Accounting Office. GAO/HEHS-95-116 Disability Fraud Program.

Gendell, Murray. 2001. "Retirement Age Declines again in 1990s" Monthly Labor Review. Vol. 124, No.10, pp 12-21.

Gendell, Murray. 2006. "Full-Time Work Among Elderly Increases." Population Reference Bureau Report. Accessed online

http://www.prb.org/Articles/2006/FullTimeWorkAmongElderlyIncreases.aspx

Haider, Steven J., Robert Schoeni, Yuhua Bao, and Caroline Danielson. 2004. Immigrants, Welfare Reform, and the Economy. Journal of Policy Analysis and Management 23(4), October:745-764.

Haskins, Ron. 2007. "The Goal of Limiting Welfare Benefits for Noncitizens: The Emergence of Compromises," Paper presented at "Immigrant Children and Families on the $10^{\text {th }}$ Anniversary of Welfare Reform.” Migration Policy Institute, Washington:DC.

Hu, Wei-Yin. 1998. "Elderly Immigrants on Welfare." Journal of Human Resources, Vol.33, No.3, 711-741.

Hu, W. Y. 2000. "Immigrant Earnings Assimilation: Estimates From Longitudinal Data." American Economic Review, 90(2):368-72.

Kaestner, Robert, and Neeraj Kaushal. 2007. Welfare Reform and Immigrants: Does the Five Year Ban Matter? Research in Labor Economics, forthcoming.

Kaushal, Neeraj. 2005. New Immigrants' Location Choices: Magnets without Welfare. Journal of Labor Economics, 23 (1): 59-80.

Lofstrom, Magnus and Frank Bean. "Assessing Immigrant Policy Options: Labor Market Conditions and Post-Reform Declines in Welfare Receipt Among Immigrants ", Demography, November 2002, 39:4, pp.617-637.

Matloff (1996). "Welfare Use Among Elderly Immigrants" Testimony to the U.S. Senate Judiciary Committee, Subcommittee on Immigration.

Parrott, Thomas M., Lenna D Kennedy, Charles G Scott. 1998. "Noncitizens and the supplemental security income program" Social Security Bulletin; 1998; 61, 4.

Passel, J. (2005). Unauthorized migrants: numbers and characteristics. Background briefing prepared for the task force on immigration and America's future. Pew Hispanic Center, Washington, DC. 
Quinn, Joseph F. "Has the Early Retirement Trend Reversed?" (unpublished paper), accessed online at http://fmwww.bc.edu/ec-p/wp424.pdf.

U.S. House Ways and Means Committee. 2004. "Background Material and Data on Programs Within the Jurisdiction of the House Ways and Means Committee" (The Green Book), Committee on Ways and Means, U.S. House of Representatives.

Van Hook, Jennifer. "Welfare Reform Chilling Effects on Non-citizens: Changes in Non-citizen Recipiency or Shifts in Citizenship Status?” Social Science Quarterly 84(3): 613-631.

Van Hook, Jennifer and Frank Bean. 1999. "The growth in noncitizen SSI caseloads 1979-1996: aging versus new immigrant effects" Journals of Gerontology Series B: Psychological Sciences and Social Sciences, Vol. 54, Issue 1 S16-S2. 
Figure 1 Number of Non-citizens Receiving Supplemental Security Income

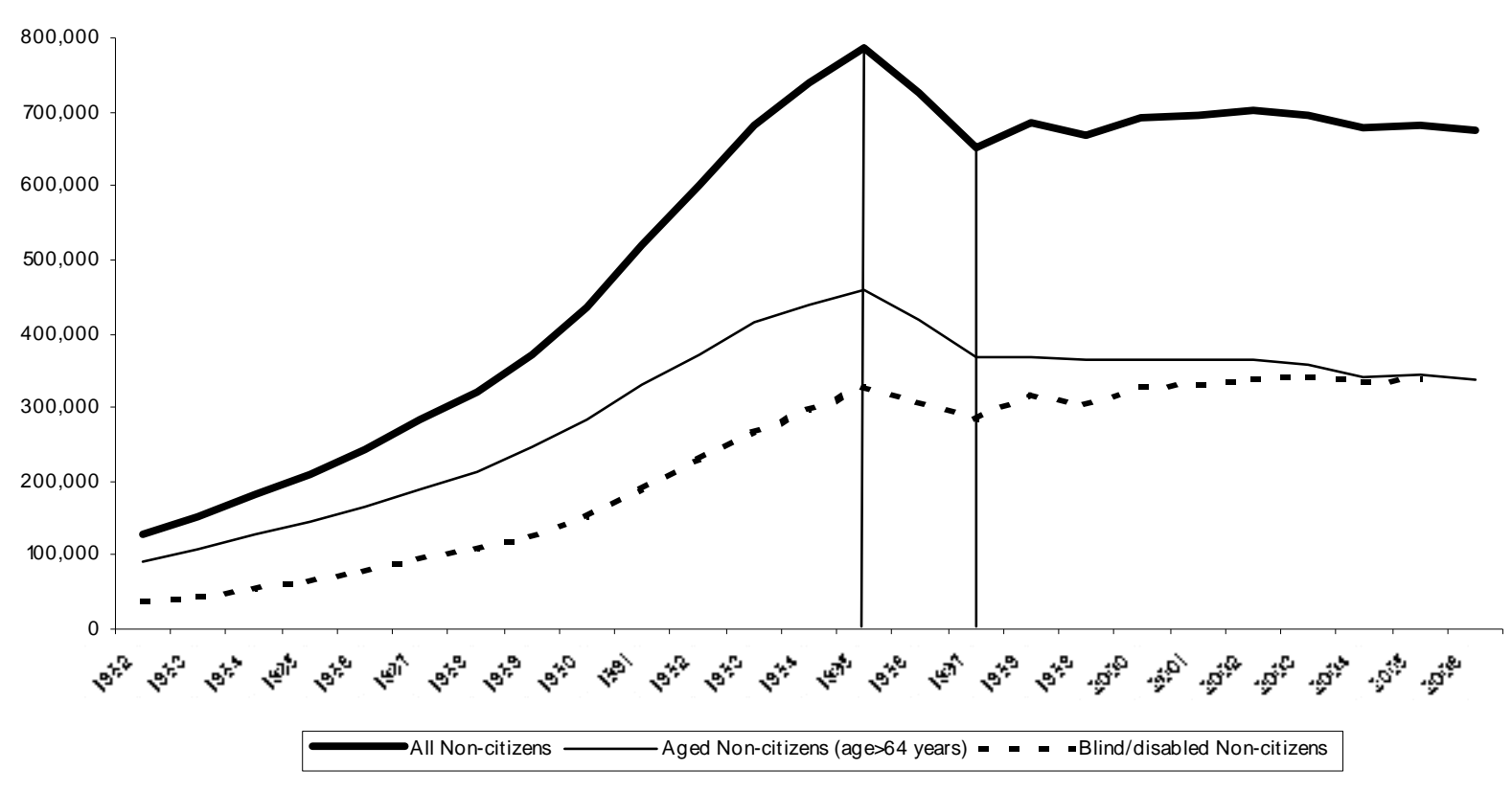

Source: Annual Statistical Supplement to the Social Security Bulletin, 2007 
Figure 2 Utilization of Supplemental Security Income

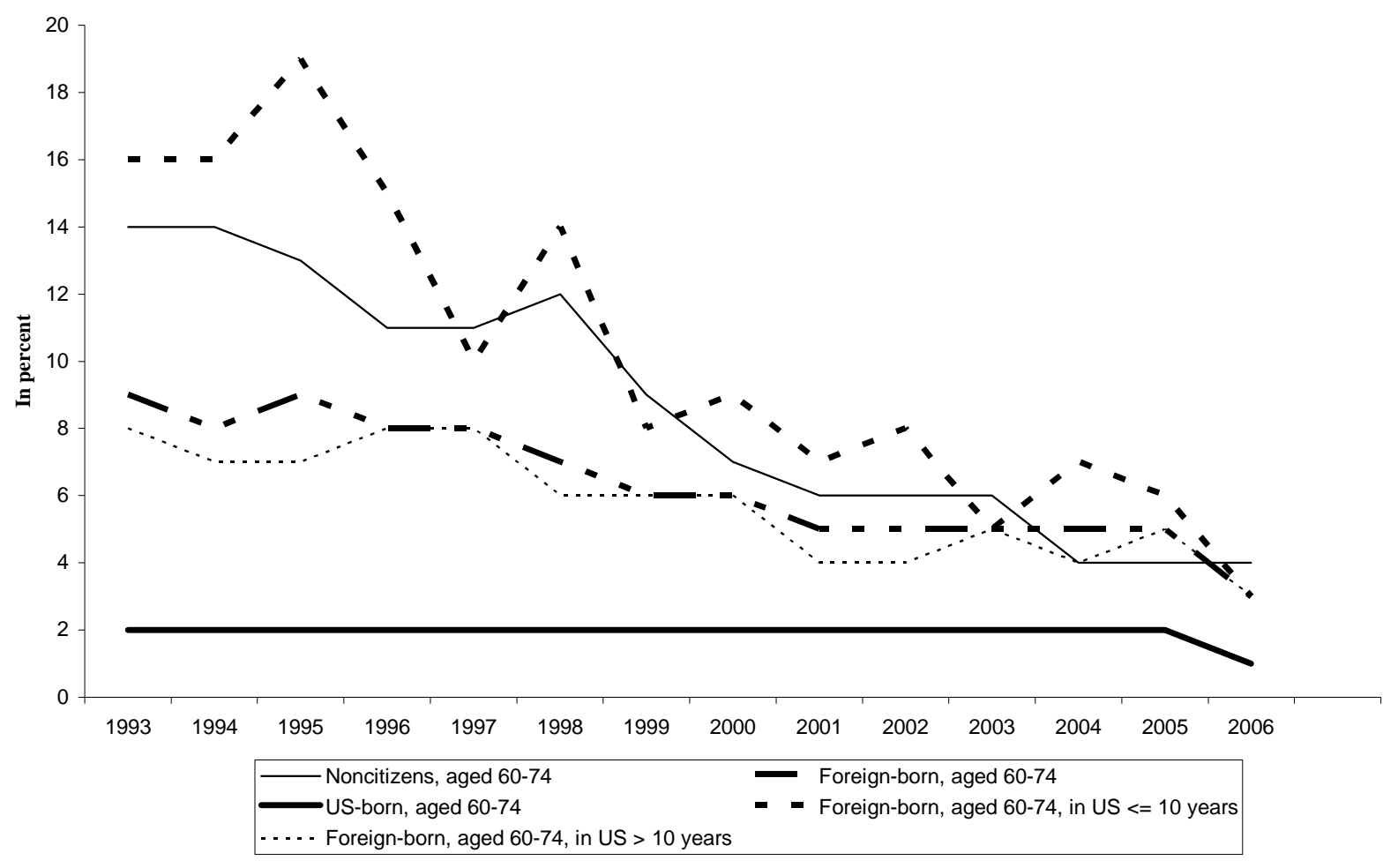

Source: March Series of the Current Population Survey, 1994-2007 
Table 1. Description of the Sample: Current Population Survey- Monthly Outgoing Rotation Files, 1994-2005.

\begin{tabular}{|c|c|c|c|c|}
\hline & \multicolumn{2}{|c|}{ Foreign-born } & \multicolumn{2}{|c|}{ US-born } \\
\hline & Men & Women & Men & Women \\
\hline \multicolumn{5}{|l|}{ Education } \\
\hline$<$ High-school & $0.34 *$ & $0.38^{*}$ & 0.21 & 0.20 \\
\hline High-school & $0.24 *$ & $0.31 *$ & 0.33 & 0.43 \\
\hline Some College & $0.13 *$ & $0.14 *$ & 0.20 & 0.22 \\
\hline BA or higher & $0.29 *$ & $0.16^{*}$ & 0.25 & 0.15 \\
\hline Proportion married & $0.78^{*}$ & $0.55^{*}$ & 0.79 & 0.59 \\
\hline \multirow{2}{*}{\multicolumn{5}{|c|}{$\begin{array}{l}\text { Labor force participation } \\
\text { 1994-1996 }\end{array}$}} \\
\hline & & & & \\
\hline Currently employed & $0.37 *$ & $0.21 *$ & 0.34 & 0.22 \\
\hline Works full-time & $0.25^{*}$ & $0.10^{*}$ & 0.19 & 0.09 \\
\hline Works part time & $0.12^{*}$ & $0.10^{*}$ & 0.15 & 0.14 \\
\hline Weekly hours worked & $14^{*}$ & 6 & 12 & 6 \\
\hline Retired & $0.57 *$ & $0.66^{*}$ & 0.63 & 0.70 \\
\hline \multicolumn{5}{|l|}{$1997-2005$} \\
\hline Currently employed & $0.44 *$ & $0.25^{*}$ & 0.38 & 0.28 \\
\hline Works full-time & $0.31 *$ & $0.13^{*}$ & 0.23 & 0.12 \\
\hline Works part time & $0.13 *$ & $0.11 *$ & 0.15 & 0.16 \\
\hline Weekly hours worked & $16^{*}$ & 8 & 14 & 8 \\
\hline Retired & $0.50 *$ & $0.64 *$ & 0.59 & 0.67 \\
\hline Citizens & 0.65 & 0.63 & -- & -- \\
\hline Proportion in US $\leq 10$ years & 0.15 & 0.16 & -- & -- \\
\hline Proportion in US $>10$ years & 0.85 & 0.84 & -- & -- \\
\hline $\mathrm{N}$ & 19025 & 25515 & 210257 & 245221 \\
\hline
\end{tabular}

Note: Samples are restricted to able-bodied elderly persons aged 60 to 74 .

$*$ denotes that the values for the foreign-born men's (women's) sample are statistically different from those for the US-born men's (women's) sample at $p<0.05$. 
Table 2. Estimated Effect of PRWORA (Denial of SSI) on Employment, Hours Worked and Retirement of Foreign-born Elderly Men

\begin{tabular}{|c|c|c|c|c|c|c|}
\hline \multirow[b]{2}{*}{$\begin{array}{l}\text { Panel } 1 \\
\text { Policy*Foreign-born }\end{array}$} & \multicolumn{2}{|c|}{ Currently Employed } & \multicolumn{2}{|c|}{ Hours Worked } & \multicolumn{2}{|c|}{ Retired } \\
\hline & $\begin{array}{l}0.027 * * * \\
(0.008)\end{array}$ & $\begin{array}{l}0.029 * * \\
(0.011)\end{array}$ & $\begin{array}{l}0.838 * * \\
(0.392)\end{array}$ & $\begin{array}{l}0.890^{*} \\
(0.521)\end{array}$ & $\begin{array}{l}-0.022 * * * \\
(0.008)\end{array}$ & $\begin{array}{l}-0.025 * * \\
(0.010)\end{array}$ \\
\hline Policy*Foreign-born, in US for $\leq 10$ years & $\begin{array}{l}0.071 * * * \\
(0.023)\end{array}$ & $\begin{array}{l}0.066^{* * * *} \\
(0.022)\end{array}$ & $\begin{array}{l}1.710^{*} \\
(0.986)\end{array}$ & $\begin{array}{l}1.674 \\
(1.029)\end{array}$ & $\begin{array}{l}-0.049 * * \\
(0.022)\end{array}$ & $\begin{array}{l}-0.044 * * \\
(0.022)\end{array}$ \\
\hline Policy*Foreign-born, in US for $>10$ years & $\begin{array}{l}0.019 * * \\
(0.008)\end{array}$ & $\begin{array}{l}0.022 * \\
(0.012)\end{array}$ & $\begin{array}{l}0.424 \\
(0.363)\end{array}$ & $\begin{array}{l}0.739 \\
(0.557)\end{array}$ & $\begin{array}{l}-0.017 * * \\
(0.007)\end{array}$ & $\begin{array}{l}-0.021 * \\
(0.011)\end{array}$ \\
\hline $\begin{array}{l}\text { Panel } 2 \\
\text { Policy*Non-citizen }\end{array}$ & $\begin{array}{l}0.046^{* * *} \\
(0.010)\end{array}$ & $\begin{array}{l}0.050 * * * \\
(0.017)\end{array}$ & $\begin{array}{l}1.521 * * * \\
(0.510)\end{array}$ & $\begin{array}{l}2.001 * * * \\
(0.728)\end{array}$ & $\begin{array}{l}-0.043 * * * \\
(0.009)\end{array}$ & $\begin{array}{l}-0.056^{* * *} \\
(0.018)\end{array}$ \\
\hline Policy*Non-citizen, in US for $\leq 10$ years & $\begin{array}{l}0.088 * * * \\
(0.026)\end{array}$ & $\begin{array}{l}0.089 * * \\
(0.033)\end{array}$ & $\begin{array}{l}2.184 * * \\
(1.066)\end{array}$ & $\begin{array}{l}2.795 * * \\
(1.282)\end{array}$ & $\begin{array}{l}-0.060 * * \\
(0.023)\end{array}$ & $\begin{array}{l}-0.069 * * \\
(0.030)\end{array}$ \\
\hline Policy*Non-citizen, in US for $>10$ years & $\begin{array}{l}0.024 \\
(0.015)\end{array}$ & $\begin{array}{l}0.028 \\
(0.017)\end{array}$ & $\begin{array}{l}0.800 \\
(0.739)\end{array}$ & $\begin{array}{l}1.571 * \\
(0.881)\end{array}$ & $\begin{array}{l}-0.035^{* *} \\
(0.010)\end{array}$ & $\begin{array}{l}-0.048 * * * \\
(0.016)\end{array}$ \\
\hline Includes state-specific trends & No & Yes & No & Yes & No & Yes \\
\hline
\end{tabular}

Note: CPS-ORG 1994-2005. The dependent variables are listed as column headings. Each figure in rows 1 and 4 is based on a separate regression, and figures in each column in rows 2-3 and rows 5-6 are also based on separate regressions that allow the effect of policy to differ by foreign-born person's length of stay in the US. All regressions include controls for age, marital status, race, education, citizenship status, length of stay in the US, month of the year, state, year and country fixed effects. Regressions in columns 2,4, and 6 also include state-specific linear trends; and state fixed effects and state specific linear trends are allowed to be different for foreign-born and US born persons in these regressions. The sample of analysis consists of elderly men aged 60 to 74 . Analysis in Panel 2 restricts the foreign-born sample to non-citizens.

$* 0.05<\mathrm{p}=<0.1, * * 0.01<\mathrm{p}=<0.05, * * * \mathrm{p}=<0.01$. 
Table 3. Estimated Effect of PRWORA (Denial of SSI) on Employment, Hours Worked and Retirement of Foreign-born Elderly Women

\begin{tabular}{|c|c|c|c|c|c|c|}
\hline \multirow[b]{2}{*}{$\begin{array}{l}\text { Panel } 1 \\
\text { Policy*Foreign-born }\end{array}$} & \multicolumn{2}{|c|}{ Currently Employed } & \multicolumn{2}{|c|}{ Hours Worked } & \multicolumn{2}{|c|}{ Retired } \\
\hline & $\begin{array}{l}-0.011^{*} \\
(0.006)\end{array}$ & $\begin{array}{l}-0.012 \\
(0.008)\end{array}$ & $\begin{array}{l}-0.247 \\
(0.241)\end{array}$ & $\begin{array}{l}-0.339 \\
(0.332)\end{array}$ & $\begin{array}{l}0.011 \\
(0.009)\end{array}$ & $\begin{array}{l}0.003 \\
(0.010)\end{array}$ \\
\hline Policy*Foreign-born, in US for $\leq 10$ years & $\begin{array}{l}-0.006 \\
(0.010)\end{array}$ & $\begin{array}{l}-0.011 \\
(0.011)\end{array}$ & $\begin{array}{l}0.030 \\
(0.491)\end{array}$ & $\begin{array}{l}-0.137 \\
(0.521)\end{array}$ & $\begin{array}{l}0.037 * * \\
(0.018)\end{array}$ & $\begin{array}{l}0.031 * * \\
(0.014)\end{array}$ \\
\hline Policy*Foreign-born, in US for $>10$ years & $\begin{array}{l}-0.012 \\
(0.007)\end{array}$ & $\begin{array}{l}-0.012 \\
(0.009)\end{array}$ & $\begin{array}{l}-0.378 \\
(0.290)\end{array}$ & $\begin{array}{l}-0.379 \\
(0.372)\end{array}$ & $\begin{array}{l}0.006 \\
(0.010)\end{array}$ & $\begin{array}{l}-0.002 \\
(0.013)\end{array}$ \\
\hline $\begin{array}{l}\text { Panel } 2 \\
\text { Policy*Non-citizen }\end{array}$ & $\begin{array}{l}-0.009 \\
(0.009)\end{array}$ & $\begin{array}{l}-0.019 * \\
(0.011)\end{array}$ & $\begin{array}{l}-0.241 \\
(0.460)\end{array}$ & $\begin{array}{l}-0.899 * \\
(0.490)\end{array}$ & $\begin{array}{l}0.019 * \\
(0.010)\end{array}$ & $\begin{array}{l}0.019 \\
(0.017)\end{array}$ \\
\hline Policy*Non-citizen, in US for $\leq 10$ years & $\begin{array}{l}-0.011 \\
(0.010)\end{array}$ & $\begin{array}{l}-0.024 \\
(0.020)\end{array}$ & $\begin{array}{l}-0.442 \\
(0.427)\end{array}$ & $\begin{array}{l}-1.084 \\
(0.786)\end{array}$ & $\begin{array}{l}0.039 * * \\
(0.017)\end{array}$ & $\begin{array}{l}0.041^{*} \\
(0.021)\end{array}$ \\
\hline Policy*Non-citizen, in US for $>10$ years & $\begin{array}{l}-0.008 \\
(0.015)\end{array}$ & $\begin{array}{l}-0.016 \\
(0.012)\end{array}$ & $\begin{array}{l}-0.230 \\
(0.639)\end{array}$ & $\begin{array}{l}-0.799 \\
(0.504)\end{array}$ & $\begin{array}{l}0.009 \\
(0.013)\end{array}$ & $\begin{array}{l}0.007 \\
(0.020)\end{array}$ \\
\hline Includes state-specific trends & No & Yes & No & Yes & No & Yes \\
\hline
\end{tabular}

Note: CPS-ORG 1994-2005. The dependent variables are listed as column headings. Each figure in rows 1 and 4 is based on a separate regression, and figures in each column in rows 2-3 and rows 5-6 are also based on separate regressions that allow the effect of policy to differ by foreign-born person's length of stay in the US. All regressions include controls for age, marital status, race, education, citizenship status, length of stay in the US, month of the year, state, year and country fixed effects. Regressions in columns 2,4, and 6 also include state-specific linear trends; and state fixed effects and state specific linear trends are allowed to be different for foreign-born and US born persons in these regressions. The sample of analysis consists of elderly women aged 60 to 74 . Analysis in Panel 2 restricts the foreign-born sample to non-citizens.

$* 0.05<\mathrm{p}=<0.1, * * 0.01<\mathrm{p}=<0.05, * * * \mathrm{p}=<0.01$ 
Table 4. Multinomial Logit Estimates of Effect of PRWORA (Denial of SSI) on Full-time and Part time Employment of Foreign-born Elderly Persons

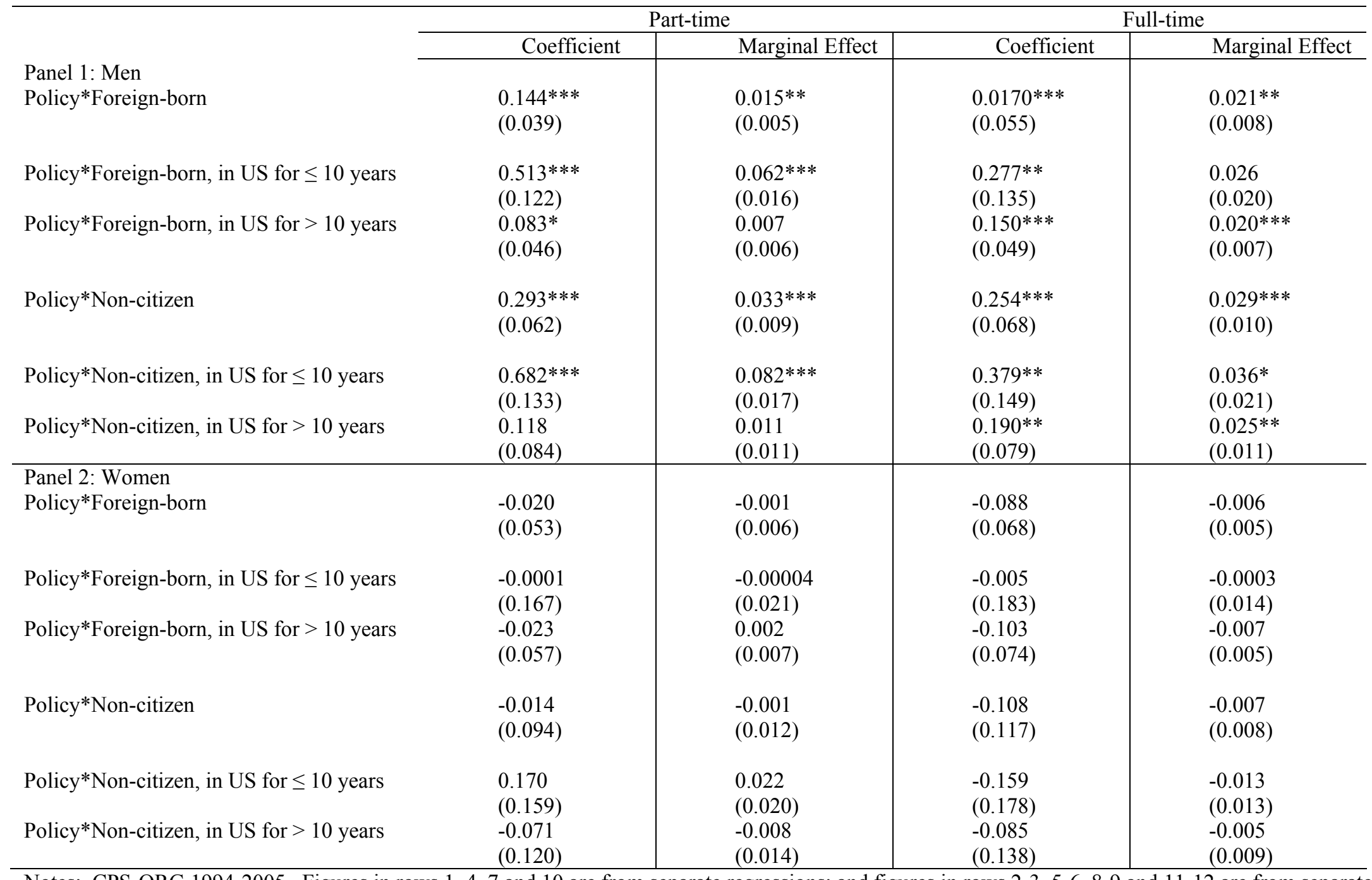

Notes: CPS-ORG 1994-2005. Figures in rows 1, 4, 7 and 10 are from separate regressions; and figures in rows 2-3, 5-6, 8-9 and 11-12 are from separate regressions in which the sample of foreign-born persons is stratified by the length of their stay in the US. Each regression includes controls for age, race, education, marital status, whether the respondent is foreign-born, their citizenship status and years of stay in the US, month of the year, year and state fixed effects. The dependent variable is a multinomial probability with three outcomes, two of which are listed as column heading and the third, the category of 
comparison, is non-workers. The sample of analysis in panel 1 consists of elderly men aged 60 to 74 , and in panel 2 , of elderly women aged 60 to 74 . Analyses in the bottom three rows of each panel restrict the foreign-born samples to non-citizens.

$* 0.05<\mathrm{p}=<0.1, * * 0.01<\mathrm{p}=<0.05, * * * \mathrm{p}=<0.01$ 
Table 5. Estimated Effect of PRWORA on Employment, Hours Worked and Retirement of non-Elderly Foreign-born Adults (aged 45-54 years)

\begin{tabular}{|c|c|c|c|c|c|c|}
\hline \multirow{2}{*}{$\begin{array}{l}\text { Men } \\
\text { Policy*Foreign-born }\end{array}$} & \multicolumn{2}{|c|}{ Currently Employed } & \multicolumn{2}{|c|}{ Hours worked } & \multicolumn{2}{|c|}{ Retired } \\
\hline & $\begin{array}{l}0.012 * * \\
(0.006)\end{array}$ & $\begin{array}{l}-0.000 \\
(0.009)\end{array}$ & $\begin{array}{l}0.617^{*} \\
(0.362)\end{array}$ & $\begin{array}{l}0.336 \\
(0.654)\end{array}$ & $\begin{array}{l}0.000 \\
(0.002)\end{array}$ & $\begin{array}{l}-0.001 \\
(0.003)\end{array}$ \\
\hline Policy*Foreign-born, in US for $\leq 10$ years & $\begin{array}{l}0.043 * * \\
(0.019)\end{array}$ & $\begin{array}{l}0.031 \\
(0.022)\end{array}$ & $\begin{array}{l}1.700^{*} \\
(0.993)\end{array}$ & $\begin{array}{l}1.408 \\
(1.290)\end{array}$ & $\begin{array}{l}-0.003 \\
(0.004)\end{array}$ & $\begin{array}{l}-0.003 \\
(0.005)\end{array}$ \\
\hline Policy*Foreign-born, in US for $>10$ years & $\begin{array}{l}0.003 \\
(0.005)\end{array}$ & $\begin{array}{l}-0.010 \\
(0.006)\end{array}$ & $\begin{array}{l}0.293 \\
(0.272)\end{array}$ & $\begin{array}{l}0.006 \\
(0.508)\end{array}$ & $\begin{array}{l}0.001 \\
(0.001)\end{array}$ & $\begin{array}{l}0.000 \\
(0.003)\end{array}$ \\
\hline $\begin{array}{l}\text { Women } \\
\text { Policy*Foreign-born }\end{array}$ & $\begin{array}{l}0.015 \\
(0.009)\end{array}$ & $\begin{array}{l}0.016 \\
(0.014)\end{array}$ & $\begin{array}{l}0.276 \\
(0.311)\end{array}$ & $\begin{array}{l}0.674 \\
(0.483)\end{array}$ & $\begin{array}{l}-0.002 \\
(0.002)\end{array}$ & $\begin{array}{l}0.001 \\
(0.003)\end{array}$ \\
\hline Policy*Foreign-born, in US for $\leq 10$ years & $\begin{array}{l}-0.002 \\
(0.013)\end{array}$ & $\begin{array}{l}0.001 \\
(0.018)\end{array}$ & $\begin{array}{l}-0.421 \\
(0.339)\end{array}$ & $\begin{array}{l}-0.008 \\
(0.498)\end{array}$ & $\begin{array}{l}-0.005 \\
(0.004)\end{array}$ & $\begin{array}{l}-0.003 \\
(0.004)\end{array}$ \\
\hline Policy*Foreign-born, in US for $>10$ years & $\begin{array}{l}0.020 * * \\
(0.010)\end{array}$ & $\begin{array}{l}0.020 \\
(0.014)\end{array}$ & $\begin{array}{l}0.477 \\
(0.355)\end{array}$ & $\begin{array}{l}0.872 \\
(0.514)\end{array}$ & $\begin{array}{l}-0.001 \\
(0.003)\end{array}$ & $\begin{array}{l}0.002 \\
(0.004)\end{array}$ \\
\hline Includes state-specific trends & No & Yes & No & Yes & No & Yes \\
\hline
\end{tabular}

Note: CPS-ORG 1994-2005. The dependent variables are listed as column headings. Each figure in rows 1 and 4 is based on a separate regression, and figures in each column in rows 2-3 and rows 5-6 are also based on separate regressions that allow the effect of policy to differ by foreign-born person's length of stay in the US. All regressions include controls for age, marital status, race, education, whether foreign-born, citizenship status, length of stay in the US, month of the year, state, year and country fixed effects. Regressions in columns 2,4, and 6 also include state-specific linear trends; and state fixed effects and state specific linear trends are allowed to be different for foreign-born and US born persons in these regressions. The sample of analysis consists of elderly men/women aged $45-54$.

$* 0.05<\mathrm{p}=<0.1, * * 0.01<\mathrm{p}=<0.05, * * * \mathrm{p}=<0.01$ 


\section{RECENT WORKING PAPERS FROM THE}

\section{CENTER FOR RETIREMENT RESEARCH AT BOSTON COLLEGE}

Economic Restructuring and Retirement in Urban China

John Giles, January 2009

Sources of Support for Pension Reform: A Cross-National Perspective

Michelle Dion and Andrew Roberts, January 2009

The Long-Term Effect of the Divorce Revolution: Health, Wealth, and Labor

Supply

Kristin Mammen, December 2008

The Response of Household Saving to the Large Shock of German Reunification Nicola Fuchs-Schündeln, November 2008

A Parsimonious Choquet Model of Subjective Life Expectancy

Alexander Ludwig and Alexander Zimper, November 2008

Risky Pensions and Household Saving Over the Life Cycle

David A. Love and Paul A. Smith, November 2008

Identifying Local Differences in Retirement Patterns

Leora Friedberg, Michael Owyang, and Anthony Webb, November 2008

What Effect Do Time Constraints Have on the Age of Retirement?

Leora Friedberg, Wei Sun, Anthony Webb, November 2008

Dual-Eligible Medicaid Spending: Are We on the Flat of the Curve?

Melissa A. Boyle, Joanna N. Lahey, and Margaret E. Czervionke, November 2008

Public Long-Term Care Insurance and the Housing and Living Arrangements of the Elderly: Evidence from Medicare Home Health Benefits

Gary V. Engelhardt and Nadia Greenhalgh-Stanley, November 2008

The Impact of Changing Earnings Volatility on Retirement Wealth Austin Nichols and Melissa M. Favreault, November 2008

All working papers are available on the Center for Retirement Research website (http://www.bc.edu/crr) and can be requested by e-mail (crr@bc.edu) or phone (617-552-1762). 